\title{
A Response to "Changing Student Perception of an Online Integrated Structured Clinical Examination During the COVID-I9 Pandemic" [Letter]
}

Lucy Mellers

Anna Chelchowska $\mathbb{D}$ Jessica Nicholls-Mindlin

Medical Sciences, University of Oxford Oxford, UK
Correspondence: Lucy Mellers

Medical Sciences Office, John Radcliffe Hospital, Headley Way, Oxford, OX3 9DU, UK

Tel +441865285783

Email Lucy.mellers@worc.ox.ac.uk

\section{Dear editor}

As final year medical students whose OSCE practice opportunities have been greatly affected by the COVID-19 pandemic, ${ }^{1}$ we were interested to read about the benefits of mock online ISCEs. ${ }^{2}$ The fast-moving nature of the pandemic meant many changes may have been made to education without an evidence base. It is reassuring now to see evaluation of these adaptations. Here we offer a medical student perspective on the methods used by Ganesananthan et al. ${ }^{2}$

Firstly, the choice of simulated patient can affect the utility of the ISCE. Mavis et $\mathrm{al}^{3}{ }^{3}$ compared the student experience of patients simulated by student peers, faculty members and actors. They found student patients, used by Ganesananthan et $\mathrm{al}^{2}$ to be the least useful, largely because of student familiarity. ${ }^{3}$ Faculty members brought domain knowledge, enabling detailed medical feedback. Use of faculty members was also beneficial for assessment; the faculty receive direct insight into student ability, so can target future teaching appropriately. However, they suggested that actors have the highest fidelity, as they are unfamiliar to the students and, in our own experience, highlight medical jargon that peers or faculty members may not notice. Therefore, introducing actors into the online ISCEs could help improve the translatability of this ISCE into real life clinical skill.

The authors assessed the students' previous exposure to an online ISCE as well as any experience of formal online interviews. However, an important factor that this study failed to address was the extent of the students' previous exposure to telemedicine. Indeed, Chandra et $\mathrm{al}^{4}$ found that telemedicine opportunities reinforced communication skills learning objectives and were positively received by students themselves, demonstrating the value of clinical telemedicine opportunities. During the pandemic some of us had many opportunities to lead telemedicine consultations during our General Practice rotation, while others practiced face-toface only. Students with more telemedicine exposure may have gained confidence and skill in online consulting. These differences must be taken into account, as they may affect perception of an online ISCE.

The study's aims were to assess perception and utility of an online ISCE, by evaluating perception before and after the mock ISCE. However, this fails to give a picture of the student's perception of an online ISCE having sat the real exam. If the mock online ISCE was too easy, students may develop a false sense of security, 
lowering the utility of the mock. Chisnall et $\mathrm{al}^{5}$ investigated the outcomes of a formative OSCE by looking at student performance and perceptions in both formative and summative OSCEs. With this method they were able to see that the majority of students felt that the formative prepared them well and reduced anxiety about the summative. We suggest that another questionnaire after the real ISCE would provide more insight into the utility of the mock.

In conclusion, this mock online ISCE could be altered in the ways we suggest, making it a more useful exercise ahead of the real exam, and ultimately helping students become better clinicians in the new era of telemedicine.

\section{Disclosure}

The authors report no conflicts of interest in this communication.

\section{References}

1. Ahmed H, Allaf M, Elghazaly H. COVID-19 and medical education. Lancet Infect Dis. 2020;20(7):777-778. doi:10.1016/S1473-3099(20) 30226-7

2. Ganesananthan S, Li C, Donnir A, et al. Changing student perception of an online integrated structured clinical examination during the COVID-19 pandemic. Adv Med Educ Pract. 2021;12:887-894. doi:10. 2147/AMEP.S325364

3. Mavis B, Turner J, Lovell K, Wagner D. DEVELOPMENTS: faculty, students, and actors as standardized patients: expanding opportunities for performance assessment. Teach Learn Med. 2006;18(2):130-136. doi:10.1207/s15328015tlm1802_7

4. Chandra S, Laoteppitaks C, Mingioni N, Papanagnou D. Zooming-out COVID-19: virtual clinical experiences in an emergency medicine clerkship. Med Educ. 2020;54(12):1182-1183. doi:10.1111/medu.14 266

5. Chisnall B, Vince T, Hall S, Tribe R. Evaluation of outcomes of a formative objective structured clinical examination for second-year UK medical students. Int J Med Educ. 2015;6:76-83. doi:10.5116/ ijme.5572.a534

Dove Medical Press encourages responsible, free and frank academic debate. The content of the Advances in Medical Education and Practice 'letters to the editor' section does not necessarily represent the views of Dove Medical Press, its officers, agents, employees, related entities or the Advances in Medical Education and Practice editors. While all reasonable steps have been taken to confirm the content of each letter, Dove Medical Press accepts no liability in respect of the content of any letter, nor is it responsible for the content and accuracy of any letter to the editor.

\section{Publish your work in this journal}

Advances in Medical Education and Practice is an international, peerreviewed, open access journal that aims to present and publish research on Medical Education covering medical, dental, nursing and allied health care professional education. The journal covers undergraduate education, postgraduate training and continuing medical education including emerging trends and innovative models linking education, research, and health care services. The manuscript management system is completely online and includes a very quick and fair peer-review system. Visit http://www.dovepress.com/testimonials.php to read real quotes from published authors. 